\title{
Apakah pengungkapan sosial memediasi hubungan antara variabel kontekstual dan kinerja keuangan? Bukti empiris pada bank syariah
}

\author{
Ratna Yudhiyati, Mahfud Sholihin* \\ Fakultas Ekonomika dan Bisnis, Universitas Gadjah Mada, Yogyakarta, Indonesia \\ ${ }^{*}$ Corresponding author. E-mail: email: mahfud@ugm.ac.id
}

\section{A R T I K E L I N F O}

\section{Article history:}

Available online 1 December 2016

\section{Keywords:}

Sharia Bank, ethical identity, social disclosure, performance

Finance.

\section{A B S T R A C T}

This study aims to examine any contextual variables that affect the level of social disclosure of sharia banks. This study also analyzes whether the level of social disclosure mediates the relationship between contextual factors and the financial performance of sharia banks. The sample of this study is 34 sharia banks from various countries during 2010-2012, so this research using panel data model. This research found that significant contextual variables affecting social disclosure are the political rights and personal freedom of a country, Muslim population, the quality of Islamic governance, economic conditions of the country, and the size of Islamic banks. This study found no significant relationship between the level of disclosure of sharia banks and performance. Thus, this study found that the level of disclosure of sharia banks does not mediate the relationship between contextual variables and performance.

\begin{abstract}
A B S T R A K
Penelitian ini bertujuan menguji variabel kontekstual apa saja yang mempengaruhi tingkat pengungkapan sosial bank syariah. Setelah itu, penelitian ini juga menganalisis apakah tingkat pengungkapan sosial memediasi hubungan antara faktor kontekstual dengan kinerja keuangan bank syariah. Sampel penelitian ini adalah 34 bank syariah dari berbagai negara selama 2010-2012, sehingga penelitian ini menggunakan model data panel.Penelitian ini menemukan bahwa variabel kontekstual yang signifikan mempengaruhi pengungkapan sosial adalah hak berpolitik dan kebebasan pribadi suatu negara, populasi muslim, kualitas Islamic governance, kondisi ekonomi negara, dan ukuran bank syariah. Penelitian ini tidak menemukan hubungan signifikan antara tingkat pengungkapan bank syariah dengan kinerja. Dengan demikian, penelitian ini menemukan bahwa tingkat pengungkapan bank syariah tidak memediasi hubungan antara variabel kontekstual dengan kinerja.
\end{abstract}

\section{Pendahuluan}

Bank syariah adalah sebuah lembaga keuangan yang beroperasi dengan tujuan untuk menerapkan prinsip ekonomi dan keuangan Islam di sektor perbankan (Hassan 1999). Operasional yang berdasarkan syariah Islam ini menuntut bank syariah untuk mengejar tujuan sosial yang merupakan salah satu nilai utama dalam Islam (Gambling dan Karim 1986). Karakter ini membuat bank syariah disebut-sebut sebagai perwakilan dari jenis baru korporasi yang memandang bahwa pencapaian tujuan sosial sama pentingnya (atau bahkan dapat lebih penting) daripada tujuan memperoleh keuntungan (Haniffa dan Hudaib 2007). Akibatnya, bank syariah memiliki tanggung jawab sosial untuk menyampaikan sejauh apa mereka telah memenuhi identitas etik mereka. Farook (2008) menilai bahwa tanggung jawab ini muncul karena dua posisi perbankan syariah, yakni sebagai sebuah lembaga yang harus memenuhi tanggung jawab religius sesuai identitasnya sekaligus menjalankan fungsi mereka sebagai sebuah lembaga keuangan.

Posisi unik bank syariah ini juga ditekankan dalam prinsip akuntabilitas menurut Islam. Islam memandang bahwa ada dua jenis akuntabilitas, yakni akuntabilitas kepada sesama manusia dan akuntabilitas kepada Allah (Triyuwono 2012). Lembaga maupun individu memiliki tanggung jawab untuk mengungkapkan informasi sejelas-jelasnya untuk membuktikan bahwa mereka telah memenuhi tanggung jawab mereka, baik tanggung jawab kepada sesama manusia maupun tanggung jawab kepada Allah. Pengungkapan sosial yang memadai adalah salah satu cara bagi bank syariah untuk memenuhi tanggung jawab ini. 
Salah satu penelitian penting terkait pengungkapan sosial bank syariah ini dilakukan oleh Haniffa dan Hudaib (2007). Mereka menilai tingkat pengungkapan sosial bank syariah dengan membandingkan informasi sosial yang ideal dengan informasi yang telah dikomunikasikan oleh bank syariah pada laporan tahunan mereka. ${ }^{1}$ Penelitian Haniffa dan Hudaib (2007) menemukan bahwa sebagian besar bank syariah tidak mengungkapkan informasi yang terkait dengan komitmen untuk masyarakat, visi dan misi, kontribusi dan pengelolaan zakat, informasi tentang manajemen puncak, serta dana sosial dan pinjaman ringan. Temuan Hanifa \& Hudaib tersebut mempertegas temuan Maali, Casson, dan Napier (2006) yang menunjukkan adanya kesenjangan antara infomasi ideal dengan informasi yang disampaikan oleh bank syariah.

Farook, Hassan, dan Lanis (2011) mencoba menjelaskan penyebab kesenjangan yang ditemukan pada penelitian-penelitian sebelumnya dengan meneliti faktor-faktor apa saja yang mempengaruhi tingkat pengungkapan sosial bank syariah. Berdasarkan analisis yang dilakukan pada 47 bank syariah di empat belas negara, Farook, Hassan, dan Lanis (2011) menemukan bahwa kondisi politik dan pemerintahan, jumlah populasi muslim di suatu negara, keberadaan mekanisme Islamic governance, dan proporsi dana Investment Accounts Holders (IAH) secara signifikan mempengaruhi tingkat pengungkapan sosial bank syariah.

Penelitian Farook, Hassan, dan Lanis (2011) telah menambah literatur tentang faktor-faktor yang mempengaruhi pengungkapan sosial bank syariah. Hanya saja, penelitian mereka mempunyai beberapa kelemahan dan masih menyisakan beberapa pertanyaan penting yang perlu dijawab. Pertama, penelitian mereka hanya meneliti faktor-faktor yang mempengaruhi pengungkapan sosial bank syariah dengan data cross-section pada tahun 2010. Dengan demikian, stabilitas model mereka, yang bisa jadi dipengaruhi efek antarwaktu, masih bisa dipertanyakan. Kedua, beberapa penelitian di bidang akuntansi menunjukkan bahwa pengungkapan sosial dan/atau pengungkapan identitas etika perusahaan berpengaruh positif terhadap kinerja (Berrone, Surroca, dan Tribó 2007; Richardson dan Welker 2001), tetapi ada sebagian penelitian yang menemukan tidak ada hubungan antara keduanya (Aerts, Cormier, dan Magnan 2008). Sebagian penelitian bahkan menemukan adanya hubungan negatif antara pengungkapan sosial dan kinerja keuangan, yang menegaskan kembali teori lama yang menentang perusahaan untuk menghabiskan sumber daya mereka dalam kegiatan sosial (Margolis dan Walsh 2003). Hanya saja, penelitian-penelitian tersebut menggunakan sampel nonperbankan syariah. Pertanyaan yang belum terjawab adalah apakah pengungkapan sosial berpengaruh terhadap kinerja keuangan bank syariah.

Penelitian ini bertujuan untuk menjawab beberapa pertanyaan tersebut dengan cara berikut. Pertama, penelitian ini memperbanyak periode observasi menjadi tiga tahun sehingga analisis dilakukan dengan model data panel. Penggunaan model data panel diharapkan dapat menangkap efek antarwaktu yang mungkin tidak tertangkap pada penelitian sebelumnya.Kedua, penelitian ini menjawab pertanyaan apakah pengungkapan sosial berpengaruh terhadap kinerja keuangan bank syariah.Selain itu, penelitian ini juga akan menguji apakah pengungkaan sosial memediasi hubungan antara faktor-faktor kontekstual dengan kinerja keuangan bank syariah.

Penelitian ini diharapkan dapat memberikan manfaat baik bagi dunia akademik maupun dunia praktik. Bagi dunia akademik, penelitian ini dapat membuktikan faktor apa saja yang mempengaruhi tingkat pengungkapan sosial bank syariah dan menjawab pertanyaan apakah tingkat pengungkapan sosial berhubungan dengan kinerja keuangan dalam konteks bank syariah. Bagi dunia praktik, penelitian ini diharapkan dapat digunakan sebagai landasan pertimbangan manajemen dalam mengambil keputusan terkait implementasi dan komunikasi kegiatan sosial maupun corporate governance bank syariah.

Bagian selanjutnya dari artikel ini adalah telaah literatur dan pengembangan hipotesis. Selanjutnya akan dibahas metode penelitian dibagian ketiga dan dilanjutkan dengan hasil di bagian keempat. Artikel ini akan ditutup dengan kesimpulan dan saran-saran untuk penelitian berikutnya.

\section{Tinjaun Pustaka dan Perumusan Hipotesis}

\section{Bank Syariah dan Tanggung Jawab Sosial}

Bank syariah (Islamic Bank) adalah sebuah lembaga keuangan yang bertujuan untuk mengaplikasikan prinsip ekonomi dan keuangan Islam di sektor perbankan. Organization of Islamic Conference (OIC) dalam Khir, Gupta, dan Shanmugam (2008) mendefinisikan bank syariah sebagai berikut:

"An Islamic bank is a financial institution whose statutes, rules, and procedures, expressly states its commitments to the principles of Islamic Shariah and to the banning of the receipt and the payment of of interest on any of its operation."

Definisi ini menegaskan bahwa perbedaan utama antara bank syariah dan konvensional adalah penerapan prinsip syariah Islam yang diklaim oleh bank syariah. Secara lebih spesifik, El-Hawary, Grais, dan Iqbal (2004)

${ }^{1}$ Haniffa \& Hudaib (2007) menggunakan istilah idealcorporate ethical identitydancommunicated corporate ethical identity 
menyampaikan bahwa ada beberapa karakter utama sistem keuangan syariah, yakni saling berbagi risiko antara pihak yang terlibat, adanya transaksi ekonomi yang melandasi kontrak (materiality), tidak boleh ada eksploitasi satu pihak ke pihak lainnya, dan tidak terlibat dengan kegiatan yang dilarang Islam. Keempat karakter utama inilah yang melandasi berbagai ciri khas bank syariah, seperti sistem bagi hvariasil, pelarangan bunga, dan sebagainya.

Salah satu identitas penting bank syariah adalah pemenuhan tanggung jawab sosial. Pada masa awal berdirinya, perbankan syariah ditujukan untuk melayani dan memberikan bantuan pada pihak-pihak yang tidak tersentuh lembaga keuangan konvensional. Contoh terbaik bank syariah awal ini adalah berdirinya Mit Ghamer Saving Bank di Mesir pada 1963 yang kemudian menginspirasi pendirian Islamic Development Bank(IDB) (Abdullah dan Chee 2012). Kepedulian sosial ini pun dilanjutkan oleh bank syariah modern. Maali, Casson, dan Napier (2006) menemukan bahwa kontrak pendirian beberapa bank syariah modern pertama mensyaratkan bank tersebut untuk melakukan kontribusi sosial. Bank yang dimaksud contohnya adalah Faisal Islamic Bank di Mesir dan Sudan, Dubai Islamic Bank, dan Jordan Islamic Bank.

Islam sendiri memang menekankan pentingnya menciptakan keadilan dan kesejahteraan bagi masyarakat untuk mencapai rahmat Allah (Haniffa dan Hudaib 2007). Pencapaian hal ini haruslah disertai dengan usaha-usaha pengembangan masyarakat dan penghapusan ekploitasi dari satu pihak ke pihak lain karena Islam memandang sesama manusia sebagai saudara (Maali, Casson, dan Napier 2006). Nilai-nilai seperti ini mengharuskan bank syariah, yang mengklaim dirinya sebagai lembaga yang berdasarkan prinsip syariah Islam, untuk memandang bahwa pencapaian tujuan sosial sama penting dengan tujuan ekonomi (Haniffa dan Hudaib 2007).

\section{Identitas Etik Bank Syariah dan Pengungkapan Sosial}

Identitas korporat adalah bentuk nyata dan ciri khas sebuah organisasi yang secara integral merupakan bagian dari gambaran dan reputasi organisasi, yang disampaikan melalui media komunikasi resmi organisasi (Balmer dan Gray 2000). Salah satu unsur dari identitas korporat adalah identitas etik korporat (Corporate Ethical Identity), yakni sekelompok kegiatan, informasi, ataupun pernyataan yang merefleksikan sikap dan keyakinan organisasi terkait permasalahan etika (Berrone, Surroca, dan Tribó 2007).

Perbankan syariah adalah salah satu contoh organisasi yang sangat terpengaruh oleh identitas korporat yang mereka bangun. Masyarakat mengenal ciri khas mereka, yakni bank yang beroperasi berdasarkan prinsip Islam. Bank syariah juga dianggap memiliki identitas etik karena masyarakat jelas menganggap bahwa nilai-nilai Islam akan selalu menjadi landasan bank terkait berbagai permasalahan etika.

Salah satu cara mengukur identitas etik bank syariah adalah melalui pengungkapan sosial yang mereka lakukan. Dalam konteks Islam, tujuan utama pelaporan lembaga keuangan syariah adalah menyampaikan kesesuaian operasi mereka dengan aturan syariah (Rahman dan Bukair 2013). Pandangan ini membuat bank syariah tidak hanya menyampaikan informasi keuangan, tetapi juga harus mengungkapkan informasi sosial. Keharusan ini merupakan dampak dari dua posisi bank syariah, yakni sebuah lembaga keuangan yang harus memenuhi tanggung jawab agama dengan tetap menjalankan fungsinya sebagai sebuah lembaga keuangan (Farook 2008).

Ada tiga penelitian penting yang menjabarkan identitas etik bank syariah menjadi beberapa dimensi. Berdasarkan indikator ini, penelitian-penelitian tersebut telah menilai sebaik apa bank syariah dalam mengungkapkan informasi untuk mendukung identitas etik mereka. Ketiga penelitian tersebut adalah Maali, Casson, dan Napier (2006); Haniffa dan Hudaib (2007); Rahman dan Bukair (2013).

Maali, Casson, dan Napier (2006) menyatakan bahwa bank syariah seharusnya mengungkapkan informasi terkait sembilan hal. Kesembilan haltersebut adalah sebagai berikut; opini Sharia Supervisory Board (SSB), transaksi haram, zakat, pembiayaan quard Hassan, kegiatan sosial, karyawan, kebijakan terkait gagal bayar, lingkungan, dan aspek lain terkait keikutsertaan bank pada berbagai komunitas. Haniffa dan Hudaib (2007) menyusun delapan dimensi identitas etik bank syariah dalam penelitian mereka. Indeks yang disusun dari kedelapan dimensi ini disebut Ethical Identity Index (EII). Kedelapan dimensi tersebut adalah sebagai berikut; pernyataan visi dan misi, Board of Director dan manajemen puncak, jenis produk dan layanan yang diberikan, ZISWAF dan dana kebajikan, komitmen kepada karyawan, dan Sharia Supervisory Board. Rahman dan Bukair (2013) mengembangkan kedua indeks pengungkapan sosial yang telah disusun sebelumnya. Mereka menggunakan indeks yang disusun Maali, Casson, dan Napier (2006) dan memasukkan beberapa dimensi pengungkapan Haniffa dan Hudaib (2007) dan kajian literatur lain dengan tujuan menyusun indeks pengungkapan sosial yang komprehensif. Ada tiga belas halutama yang termasuk dalam indek ini, yaitu; pernyataan visi dan misi, Sharia Supervisory Board (SSB), transaksi haram, zakat, pembiayaan quard Hassan, kegiatan sosial, karyawan, kebijakan terkait gagal bayar, lingkungan, produk dan layanan, pelanggan, kemisikinan, serta keikutsertaan bank pada berbagai komunitas.

Tiga penelitian terdahulu tersebutmenemukan bahwa sebagian besar bank syariah belum mengungkapkan informasi sebagaimana seharusnya dan ada kesenjangan yang besar antara pengungkapan satu bank dengan bank lainnya (Maali, Casson, dan Napier 2006; Haniffa dan Hudaib 2007). Penelitian Haniffa dan Hudaib 
(2007) juga menemukan bahwa sebagian besar bank syariah tidak mengungkapkan informasi yang terkait dengan komitmen untuk masyarakat, visi dan misi, kontribusi dan pengelolaan zakat, informasi tentang manajemen puncak, serta dana sosial dan pinjaman kebajikan.

\section{Kondisi politik-pemerintahan dan pengungkapan sosial}

Tingkat pengungkapan dan pelaporan organisasi cenderung menurun seiring dengan semakin meningkatnya tekanan sosial dan semakin banyaknya pelanggaran hak pribadi dan kebebasan politik Riahi-Belkaoui dan Belkaoui (1985) Dan juga Williams (1999) menyampaikan bahwa pelanggaran hak berpolitik dan kebebasan pribadi seringkali merupakan dampak dari sistem pemerintahan dan struktur politik yang membatasi hak dan kebebasan berpolitik dan informasi.

Pada negara yang cenderung represif, seluruh entitas memiliki hak dan kewajiban yang sangat terbatas dalam menyampaikan informasi sosial, bahkan bagi entitas sosial sekalipun. Akibatnya, ekspekstasi sosial yang diterima perusahaan dari masyarakat akan lebih rendah sehingga perusahaan tidak terdorong untuk mengungkapkan informasi diluar informasi wajib. Pada negara yang cenderung bebas, organisasi akan lebih dituntut untuk membuktikan kapasitas dan kontribusi mereka sehingga pengungkapan sosial menjadi diperlukan (Williams 1999).

Hipotesis yang akan diuji berdasarkan penjelasan tersebut adalah:

$\mathrm{H}_{1}$ : Hak berpolitik dan kebebasan pribadi di suatu negara berengaruh positifterhadap tingkat pengungkapan sosial bank syariah di negara tersebut

\section{Populasi Masyarakat Muslim dan Pengungkapan Sosial}

Teori legitimasi memandang bahwa organisasi terikat dengan kontrak sosial dengan masyarakat sekitar. Berdasarkan kontrak sosial ini, masyarakat akan mengizinkan organisasi untuk terus beroperasi selama organisasi dapat memenuhi harapan mereka terhadap organisasi ini. Asumsi yang digunakan pada teori ini juga memandang bahwa kegagalan organisasi memenuhi ekspektasi masyarakat dapat berakibat pada pemberian 'sanksi' oleh masyarakat, baik langsung maupun tidak langsung (Newson dan Deegan 2002). Contoh sanksi ini dapat bervariasi mulai dari penurunan jumlah konsumen perusahaan hingga penutupan paksa perusahaan atas tuntutan masyarakat.

Sesuai dengan teori legitimasi, Deegan, Rankin, dan Tobin (2002) menyampaikan bahwa manajemen bereaksi terhadap anggapan masyarakat tentang organisasi. Akan tetapi, Newson dan Deegan (2002)menekankan bahwa masyarakat yang paling menjadi perhatian manajemen adalah masyarakat yang terlibat langsung atau memiliki kepentingan terhadap organisasi, yang disebut 'publik relevan'. Pengungkapan adalah salah satu cara organisasi untuk menciptakan legitimasi melalui penciptaan kesan bahwa perusahaan telah berjalan sesuai ekspektasi ‘publik relevan’ tersebut (Deegan, Rankin, dan Tobin 2002).

Dalam konteks bank syariah, dapat disimpulkan bahwa masyarakat berekspektasi bahwa bank syariah seharusnya menjalankan kegiatan sesuai nilai-nilai Islam. Oleh karena itu, bank harus mengungkapkan informasi terkait hal tersebut demi memperoleh legitimasi (Khan 2010), terutama karena masyarakat muslim adalah salah satu bagian utama dari 'publik relevan' bank syariah. Sulaiman dan Willett 2003) juga menekankan bahwa bank syariah memang seharusnya mengungkapkan informasi sosial lebih banyak jika beroperasi di negara berpenduduk mayoritas muslim.

Hipotesis yang disusun berdasarkan penjelasan diatas adalah:

$\mathrm{H}_{2}$ : Proporsi penduduk muslim di suatu negara berpengaruh positif terhadap tingkat pengungkapan sosial bank syariah di negara tersebut.

\section{Mekanisme Islamic Governance dan Pengungkapan Sosial}

Corporate governance memiliki peran penting hampir di semua lembaga, tidak terkecuali bagi bank syariah. Struktur corporate governance di bank syariah sedikit berbeda dengan lembaga konvensional lain karena adanya unsur penting yang berfungsi untuk menjamin kesesuaian operasi bank syariah dengan aturan Islam, yakni Sharia Supervisory Board(SSB). Mekanisme yang dijamin oleh SSB inilah yang disebut Islamic Governance.

SSB adalah bagian tak terpisahkan dari Corporate Governance bank syariah. AAOIFI (2003) menyatakan bahwa SSB berkewajiban untuk mengarahkan dan mengawasi agar transaksi di bank syariah tidak bertentangan dengan prinsip Islam. Oleh karena itu, SSB harus menyampaikan laporan terkait kesesuaian bank syariah dengan prinsip Islam yang berfungsi sebagai penjamin untuk pada stakeholders (Maali, Casson, dan Napier 2006)

Rahman dan Bukair (2013)menemukan bahwa karakter SSB ternyata memang mempengaruhi tingkat pengungkapan sosial bank syariah. Karakter yang memiliki pengaruh signifikan adalah jumlah anggota, keanggotaan-ganda, kualifikasi doktor, dan reputasi anggota. Keempat karakter ini menentukan kualitas Islamic Governance bank syariah (Farook, Hassan, dan Lanis 2011; Rahman dan Bukair 2013). 
Hipotesis yang akan diuji berdasarkan penjelasan diatas adalah:

$\mathrm{H}_{3}$ : Kualitas Islamic Governanceberpengaruh positif terhadap tingkat pengungkapan sosial bank syariah.

\section{Proporsi Dana IAH dan Pengungkapan Sosial}

Bank syariah berbeda dengan lembaga keuangan konvensional karena keberadaan investor yang berinvestasi dalam bentuk dana simpanan pada bank yang disebut Investment Accounts Holders (IAH). Berbeda dengan pemegang saham, IAH tidak memiliki hak untuk ikut serta dalam internal bank. Cara yang tersedia bagi mereka dalam mengkritik bank terkait adalah dengan menarik dana yang mereka investasikan melalui bank tersebut jika kebijakan investasi bank tidak sesuai dengan kehendak mereka (Archer, Karim, dan Al-Deehani 1998)

Namun, jika penarikan dana ini sampai terjadi, pihak bank akan sangat dirugikan karena dana pihak ketiga adalah sumber pendanaan yang murah, dan dapat meningkatkan nilai yang diperoleh pemegang saham (Al-Deehani, Karim, dan Murinde 1999). Akibatnya, pihak pemegang saham akan mendorong manajemen untuk menyampaikan berbagai informasi yang dapat meyakinkan IAH untuk tetap menginvestasikan dana mereka di bank tersebut (Archer, Karim, dan Al-Deehani 1998). Dorongan ini akan semakin kuat seiring dengan semakin besarnya proporsi dana IAH yang dikelola bank.

Berdasarkan penjelasan diatas, hipotesis yang akan diuji adalah:

$\mathrm{H}_{4}$ : Proporsi dana IAH berpengaruh positif terhadap tingkat pengungkapan sosial bank syariah.

\section{Kondisi Ekonomi Negara dan Pengungkapan Sosial}

Beberapa argumen menyatakan bahwa kondisi perekonomian suatu negara berpengaruh terhadap tingkat pengungkapan informasi lembaga yang berada di negara tersebut.Pengaruh ini disebabkan karena negara yang memiliki kondisi ekonomi lebih baik cenderung menuntut keterbukaan informasi lebih banyak daripada negara dengan kondisi ekonomi kurang baik (Xiao et al. 2005). Doupnik dan Salter (1995) dan juga Williams (1999) menyatakan bahwa seharusnya terdapat kenaikan tingkat pengungkapan sosial seiring dengan semakin membaiknya kondisi ekonomi suatu negara.

Berdasar argumen diatas, hipotesis yang akan diuji adalah:

$\mathrm{H}_{5}$ : Kondisi Ekonomi Negara berpengaruh positif terhadap tingkat pengungkapan sosial bank syariah.

\section{Pengungkapan Sosial dan Kinerja Keuangan}

Hubungan antara pengungkapan sosial dan kinerja perusahaan merupakan topik yang sudah banyak diteliti.Akan tetapi, berbagai teori dan penelitian yang ada saat ini menemukan hasil yang berbeda tentang bagaimana hubungan antara pengungkapan sosial dan kinerja perusahaan.

Beberapa penelitian menemukan hubungan positif antara pengungkapan sosial dan kinerja perusahaan. Richardson dan Welker (2001) menjelaskan bahwa pengungkapan sosial dapat mengurangi cost of capital perusahaan. Berrone, Surroca, dan Tribó 2007) menemukan bahwa corporate revealed ethics (CRE) berdampak positif pada nilai pemegang saham. Al-Tuwaijri, Christensen, dan Hughes (2004) juga menemukan bahwa pengungkapan informasi lingkungan tentang operasi perusahaan berkorelasi positif dengan kinerja keuangan.

Namun, sebagian peneliti memandang bahwa hubungan antara kedua variabel ini belum dapat disimpulkan hingga sekarang karena ada juga penelitian yang menemukan ketiadaan hubungan antara keduanya. Aerts, Cormier, dan Magnan (2008) menemukan bahwa pengungkapan informasi lingkungan melalui 10-K form ternyata tidak secara signifikan mempengaruhi rekomendasi analis terhadap suatu perusahaan. Hasil sejenis juga ditemukan penelitian McWilliams dan Siegel (2000) yang menunjukkan bahwa pengungkapan sosial tidak mempengaruhi kinerja keuangan setelah mengontrol investasi penelitian dan pengembangan perusahaan.

Sebagian peneliti memandang bahwa banyaknya penelitian yang menganalisis hubungan antara pengungkapan sosial dan kinerja keuangan ini adalah sebuah upaya untuk melegitimasi tuntutan masyarakat terhadap perusahaan (Margolis dan Walsh 2003). Pandangan baru yang berusaha menekankan pentingnya kegiatan sosial bagi perusahaan ini justru bertentangan dengan pola pikir manajemen yang seharusnya berusaha untuk mengutamakan keuntungan pemegang saham. Pihak ini memandang bahwa kegiatan sosial dan penyampaiannya menambah biaya bagi perusahaan.Pandangan ini dibuktikan oleh adanya penelitian yang menemukan hubungan negatif antara pengungkapan sosial dan kinerja, seperti sebagian hubungan negatif yang ditemukan (Hillman dan Keim 2001).

Sesuai dengan temuan Richardson dan Welker (2001), Berrone, Surroca, dan Tribó (2007), dan AlTuwaijri, Christensen, dan Hughes (2004), penelitian ini menduga bahwa pengungkapan sosial bank syariah akan mempengaruhi kinerja keuangan bank syariah. Dengan demikian, hipotesis yang akan diuji adalah:

$\mathrm{H}_{6}$ : Pengungkapan sosial berpengaruhterhadap kinerja keuangan bank syariah. 
Setelah memaparkan bahwa hak berpolitik dan kebebasan pribadi, proporsi penduduk muslim kualitas Islamic Governance, proporsi dana IAH, dan kondisi perekonomian negara berpengaruh terhadap tingkat pengungkapan sosial bank syariah dan tingkat pengungkapan sosial bank berpengaruh terhadap kinerja keuangan bank syariah, maka dirumuskan hipotesis sebagai berikut:

$\mathrm{H}_{7}$ : Hak berpolitik dan kebebasan pribadi, proporsi penduduk muslim kualitas Islamic Governance, proporsi dana IAH, dan kondisi perekonomian negara berpengaruh terhadap kinerja keuangan bank syariah melalui tingkat pengungkapan sosial sebagai variabel pemediasi.

Hipotesis-hipotesis yang akan diuji digambarkan dalam model seperti di Gambar 1

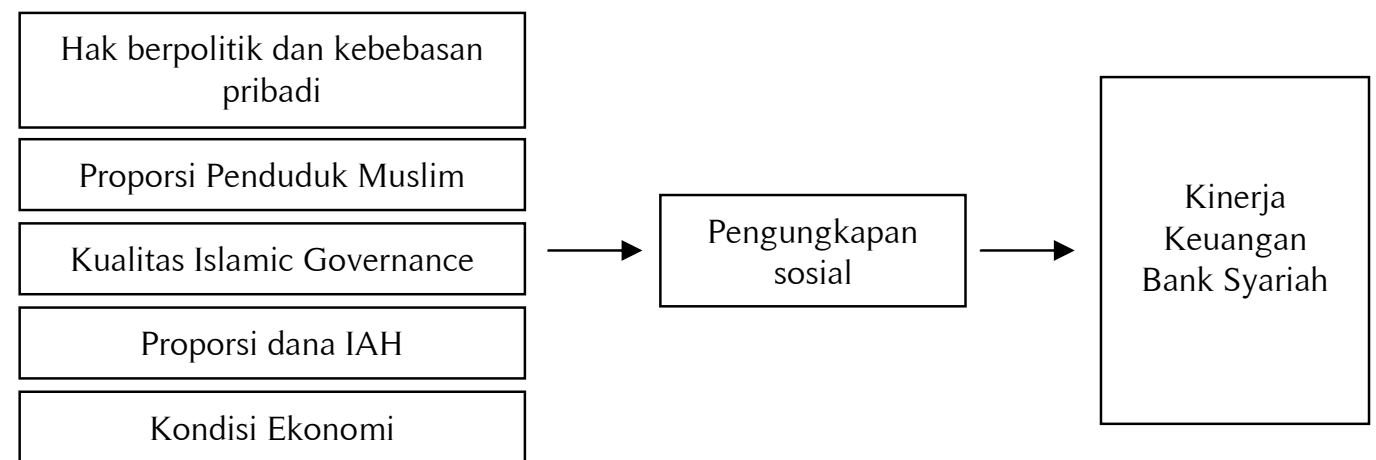

Gambar 1. Hubungan Antar Variabel

\section{Metoda Penelitian}

\section{Populasi dan Sampel Penelitian}

Populasi dari penelitian ini adalah semua full-fledged Islamic bank di dunia. Full-fledged Islamic bankadalah bank yang operasinya telah sesuai syariah, sehingga layanan keuangan syariah tidak hanya sebagai layanan tambahan selain layanan konvensional (Islamic Window). Bank syariah tersebut dapat berupa bank syariah yang telah merupakan entitas terpisah, atau masih berupa anak perusahaan dari sebuah banking group (Islamic subsidiary).

Sampling frame penelitian ini adalah bank syariah yang termasuk dalam daftar bank terbaik yang dikeluarkan oleh Global Capital (2013) dan Global Finance (2011, 2012, 2013), serta lima puluh bank terbesar dunia 2009 yang dipublikasikan oleh The Asian Banker (2010). Pemilihan sampel dalam penelitian ini menggunakan purposive sampling. Kriteria yang digunakan dalam pemilihan sampel adalah sebagai berikut.

1. Laporan tahunan sampel untuk periode 2010 - 2012 dapat diperoleh dari laman resmi, laman pasar modal terkait, ataupun sumber lain.

2. Laporan tahunan memiliki periode yang sama (1 Januari - 31 Desember).

3. Data lain tentang perusahaan yang terkait dengan variabel-variabel yang digunakan dalam penelitian tersedia dengan lengkap.

Metode ini berhasil menentukan 34 bank syariah sebagai sampel penelitian. Komposisi asal negara dari seluruh sampel tersebut adalah sebagai berikut: Bahrain (6), Kuwait (2), UAE (3), Qatar (3), Arab Saudi (1), Sudan (3), Turki (3), Bangladesh (1), Pakistan (1), Yordania (1), Malaysia (4), Indonesia (2), Brunei Darussalam (1), Tunisia (1), Afrika Selatan (1), dan Inggris (1).

\section{Variabel dan Pengukurannya}

\section{Variabel dependen}

Variabel dependen dalam penelitian ini adalah kinerja keuangan. Kinerja keuangan pada penelitian ini diukur menggunakan Return on Assets (ROA). ROA menunjukkan kemampuan manajemen untuk memanfaatkan aset dan investasi untuk menghasilkan keuntungan. ROA merupakan salah satu ukuran yang sering digunakan untuk mengukur kinerja keuangan sektor perbankan, bahkan perbankan syariah (Sufian 2010; Sehrish et al. 2012).

\section{Variabel pemediasi}

Variabel pemediasi pada penelitian ini diukur menggunakan Ethical Identity Index (EII). Ada beberapa indeks yang telah digunakan dalam menilai tingkat pengungkapan sosial bank syariah, yakni indeks yang disusun oleh 
Maali, Casson, dan Napier (2006), Haniffa dan Hudaib (2007), dan Rahman dan Bukair (2013). Penelitian ini menggunakan indeks yang disusun oleh Haniffa dan Hudaib (2007), yakni Ethical Identity Index (EII). Pemberian skor dilakukan secara dichotomous, yakni untuk setiap sampel akan memperoleh skor 1 jika mengungkapkan informasi, skor 0 jika tidak mengungkapkan informasi, terkait setiap hal. Rumusnya adalah sebagai berikut.

$$
E I I=\frac{\sum_{t=1}^{\mathrm{n}_{\mathrm{j}}} \mathrm{X}_{\mathrm{IJ}}}{\mathrm{n}_{\mathrm{j}}}
$$

EII adalah ethical identity index. $n_{j}$ adalah total seluruh item yang seharusnya diungkapkan oleh bank syariah ke-j. $X_{i j}$ bernilai 1 jika bank mengungkapkan hal tersebut, 0 jika tidak.

Data untuk EII menggunakan analisis isi (content analysis) laporan keuangan. Content analysis membutuhkan perhatian khusus pada reliabilitas data. Ada dua cara yang dapat digunakan untuk menjamin reliabilitas pada analisis ini. Pertama, penggunaan dua orang atau lebih peneliti dalam proses pemasukan data. Kedua, cukup menggunakan seorang peneliti dalam proses pemasukan data, tetapi peneliti tersebut telah memperoleh pelatihan yang memadai dan menggunakan standar yang tidak ambigu (Milne dan Adler 1999). Cara pertama adalah cara yang digunakan dalam penelitian ini. Dua orang peneliti memasukkan data dengan standar yang sama, kemudian dilanjutkan dengan diskusi dan pengecekan kembali jika ada perbedaan yang muncul.

\section{Variabel Independen}

\section{PRCL Score}

Ukuran PRCL (Political Rights, Civil Liberty) yang digunakan dalam penelitian ini adalah indeks yang dirilis oleh Freedom in the World $(2011,2012,2013)$. Ukuran yang digunakan memiliki rentang nilai 1 (paling baik) hingga 7 (paling buruk).Ukuran ini telah digunakan oleh Farook, Hassan, dan Lanis (2011) dan Williams (1999).

\section{MUSPOP}

Ukuran yang digunakan pada variabel ini adalah proporsi antara jumlah penduduk muslim yang terdata dengan total populasi pada negara tersebut. Sumber informasi diperoleh dari CIA (2013).

\section{IG SCORE}

IG Score diukur berdasarkan total nilai dari setiap karakter Sharia Supervisory Board(SSB). Setiap karakter SSB diukur secara dichotomous sebagai berikut; nilai 1 jika memiliki SSB dan 0 jika tidak, nilai 1 jika anggota SSB lebih dari lima orang dan 0 jika tidak, nilai 1 jika ada anggota SSB yang memiliki keanggotaan di tempat lain (cross-directorship) dan 0 jika tidak, nilai 1 jika ada anggota SSB yang memiliki kualifikasi doktor dan 0 jika tidak, serta nilai 1 jika ada ahli bereputasi baik dan 0 jika tidak. Informasi tentang hal ini diambil dari laporan tahunan dan laman resmi bank syariah tersebut. Ukuran ini telah digunakan oleh Farook, Hassan, dan Lanis (2011) dan Rahman dan Bukair (2013).

\section{IAH}

Variabel IAH ini diukur dengan menggunakan proporsi antara total dana IAH dengan total aset bank syariah terkait Farook, Hassan, dan Lanis (2011). Informasi tentang hal ini diambil dari laporan tahunan bank syariah.

\section{GDP}

Kondisi ekonomi negara diukur menggunakan GDP per kapita negara untuk setiap tahun observasi. Informasi tentang hal ini diambil dari IMF (2013).

\section{Variabel kontrol}

Penelitian ini memasukkan jumlah aset sebagai variabel kontrol. Variabel ini diukur dengan nilai natural log dari total aset yang telah dikonversi menjadi dolar Amerika dengan kurs akhir tahun terkait. Ukuran perusahaan telah digunakan sebagai variabel kontrol dalam banyak penelitian tentang pengungkapan sosial sebelumnya (Williams 1999; Berrone, Surroca, dan Tribó 2007).

\section{Model Penelitian}

Penelitian ini menggunakan tiga model regresi. Regresi pertama digunakan untuk menguji $\mathrm{H}_{1}$ sampai $\mathrm{H}_{5}$. Regresi kedua dan ketiga digunakan untuk menguji $\mathrm{H}_{6}$ dan $\mathrm{H}_{7}$.

MetodeRegresi pertama ditujukan untuk menguji pengaruh variabel independen pada variabel pemediasi. Regresi kedua ditujukan untuk menguji apakah terdapat pengaruh variabel independen dengan 
variabel dependen. Regresi Ketiga ditujukan untuk menguji peran variabel pemediasi dengan memasukkan variabel pemediasi sebagai variabel kontrol. Data yang digunakan berasal dari 34 sampel dan dalam rentang waktu tiga tahun, 2010-2012, sehingga penelitian ini menggunakan model data panel.

Regresi pertama adalah sebagai berikut.

EII $=\alpha+\beta_{1}$ PRCL $_{i t}+\beta_{2}$ MUSPOP $_{i t}+\beta_{3}$ IGSCORE $_{i t}+\beta_{4}$ IAH $_{i t}+\beta_{5}$ ASET $_{i t}+\beta_{6}$ GDP $_{i t}+\varepsilon_{i t}$

Regresi kedua adalah sebagai berikut.

$\mathrm{ROA}=\alpha+\beta_{1} \mathrm{EII}+\varepsilon_{\mathrm{jt}}$

Regresi ketiga yang digunakan untuk menguji apakah peran variabel pemediasi full mediation atau partial mediation ${ }^{2}$ adalah sebagai berikut;

$$
\mathrm{ROA}=\alpha+\beta_{1} \mathrm{EII}_{\mathrm{it}}+\beta_{2} \mathrm{PRCL}_{\mathrm{it}}+\beta_{3} \mathrm{MUSPOP}_{\mathrm{it}}+\beta_{4} \mathrm{IGSCORE}_{\mathrm{it}}+\beta_{5} \mathrm{IAH}_{\mathrm{it}}+\beta_{6} \mathrm{ASET}_{\mathrm{it}}+\beta_{7} \mathrm{GDP}_{\mathrm{it}}+\varepsilon_{\mathrm{it}}
$$

Berikut adalah penjelasan untuk tiap variable.

ROA : Return on Asset (Ukuran Kinerja Keuangan)

EII : Ethical Identity Index (Ukuran Tingkat Pengungkapan Sosial)

PRCL : Hak berpolitik dan kebebasan pribadi

MUSPOP : Proporsi penduduk muslim di suatu negara

IGSCORE : Kualitas Islamic Governance

IAH : Proporsi dana investasi (IAH)

ASET : Natural log dari aset total bank dalam US\$

GDP : GDP per kapita tiap negara (Ukuran Kondisi Ekonomi)

\section{Hasil Penelitian dan Pembahasan}

\section{Hasil Statistik Deskriptif dan Analisis Korelasi}

Tabel 1 di bawah ini menunjukkan hasil pengukuran statistik deskriptif semua variabel dalam penelitian ini, sedangkan Tabel 2 menunjukkan korelasi antarvariabel.

Tabel 1. Hasil Statistik Deskriptif

\begin{tabular}{lccccc}
\hline \multicolumn{1}{c}{ Variabel } & Mean & Median & Max & Min & Std. Deviasi \\
\hline ROA & 0,009039 & 0,014658 & 0,043174 & $-0,262651$ & 0,034099 \\
EII & 0,408294 & 0,391304 & 0,64 & 0,072464 & 0,126427 \\
PRCL & 4,794118 & 5,5 & 7 & 1 & 1,525936 \\
MUSPOP & 0,751824 & 0,746000 & 0,995 & 0,017 & 0,217251 \\
IGSCORE & 3,807692 & 4 & 5 & 0 & 1,351568 \\
IAH & 0,501162 & 0,579806 & 0,873281 & 0 & 0,256095 \\
GDP & $26.993,86$ & $21.968,49$ & $100.888,6$ & $1.709,303$ & $25.645,84$ \\
ASET & 22,08216 & 22,27586 & 24,99144 & 18,89381 & 1,412795 \\
\hline
\end{tabular}

Tabel 2. Spearman Rank Correlation Matrix

\begin{tabular}{|c|c|c|c|c|c|c|c|}
\hline Variabel & ROA & EII & PRCL & MUSPOP & IGSCORE & IAH & GDP \\
\hline ROA & 1 & & & & & & \\
\hline EII & $-0,005$ & 1 & & & & & \\
\hline PRCL & $-0,058$ & $-0,097$ & 1 & & & & \\
\hline MUSPOP & $0,322 \cdots$ & $-0,086$ & 0,1232 & 1 & & & \\
\hline IGSCORE & $-0,165$ & 0,187 & 0,317 & $-0,406$ & 1 & & \\
\hline IAH & 0,114 & $0,337 \cdots$ & $-0,47 \cdots$ & $-0,086$ & 0,015 & 1 & \\
\hline GDP & $-0,29 \cdots$ & $-0,078$ & 0,169 & $-0,552 \ldots$ & 0,344 & $-0,192$ & 1 \\
\hline ASET & $0,327 \cdots$ & 0,170 & $-0,121$ & $-0,031$ & 0,061 & 0,146 & $0,328 \cdots$ \\
\hline
\end{tabular}

${ }^{2}$ Untuk untuk menguji apakah peran variabel pemediasi full mediation atau partial mediation, penulis menggunakan pendekatan yang dipakai oleh Rucker et al. (2011). 


\section{Pemilihan Model Data Panel}

Model data panel terdiri dari tiga jenis model, yakni Fixed effect model(FEM), Random Effect Model(REM), dan Pooled Least Square model(PLS). Regresi 1 menggunakan pooled least square model(PLS), sedangkan Regresi 2 dan Regresi 3 menggunakan random effect model(REM). ${ }^{3}$ Model PLS diestimasi menggunakan estimasi ordinary least square (OLS) sehingga membutuhkan uji asumsi klasik sebelum hasil estimasi dapat diinterpretasikan.

Dua asumsi klasik yang menjadi perhatian dalam penelitian ini adalah heteroskedastisitas dan autokorelasi. Perhatian ini diberikan karena model data panel memiliki potensi kedua masalah ini karena merupakan gabungan data yang bersifat cross section dan time series (Gujarati dan Porter 2009).

Uji heteroskedastisitas untuk ketiga regresi ini menggunakan Uji Park. Hasil pengujian menunjukkan bahwa Regresi 1 mengalami masalah heteroskedastisitas dan autokorelasi. Oleh karena itu harus dilakukan koreksi. Koreksi terhadap dua masalah ini dilakukan dengan menggunakan white diagonal coefficient covariance method pada proses estimasi dengan program statistik.

\section{Hasil Analisis Regresi dan Pengujian Hipotesis}

Penelitian ini memiliki tujuh hipotesis yang diuji menggunakan tiga model regresi. $\mathrm{H}_{1}$ hingga $\mathrm{H}_{5}$ diuji menggunakan model regresi pertama, sedangkan $\mathrm{H}_{6}$ dan $\mathrm{H}_{7}$ diuji menggunakan model regresi kedua dan ketiga. Data penelitian ini bersifat cross-section maupun time-series sehingga penelitian ini menggunakan model data panel. Hubungan antara Hak berpolitik dan kebebasan pribadi, populasi muslim, kualitas Islamic Governance, proporsi IAH, dan kondisi ekonomi negara terhadap pengungkapan sosial. Analisis data menggunakan model regresi pertama untuk pengujian $\mathrm{H}_{1}$ hingga $\mathrm{H}_{5}$ menunjukkan hasil sebagai berikut.

Tabel 3. Hasil Regresi 1 untuk Hubungan antara Variabel Independen dan Variabel Pemediasi (EII) - PLS Model

\begin{tabular}{lccc}
\hline \multicolumn{1}{c}{ Variabel } & Prediksi Hubungan & Koefisien & Prob-value \\
\hline Konstan & & $-0,163338$ & 0,3367 \\
PRCL & - & $-0,021875$ & 0,0964 \\
MUSPOP & + & 0,138590 & 0,0731 \\
IGSCORE & + & 0,046889 & 0,0000 \\
IAH & + & 0,059223 & 0,3159 \\
GDP & + & $-9,62 \mathrm{E}-07$ & 0,0254 \\
ASET & + & 0,017666 & 0,0393 \\
& & \multicolumn{2}{c}{0,217615} \\
\multicolumn{2}{c}{0,000044} \\
\hline
\end{tabular}

Hasil estimasi yang disampaikan pada Tabel 3 menunjukkan beberapa hasil menarik. Hampir semua variabel secara statistik signifikan mempengaruhi nilai EII, kecuali variabel IAH yang memiliki nilai probabilitas diatas sepuluh persen. Variabel PRCL dan MUSPOP signifikan pada significance-leve/ sepuluh persen, variabel GDP dan ASET signifikan pada significance-level lima persen, sedangkan variabel IGSCORE signifikan pada significancelevelsatu persen.

Koefisien variabel PRCL secara statistik signifikan pada nilai negatif (-0,021875). Nilai negatif ini sesuai dengan prediksi dan menunjukkan bahwa $\mathrm{H}_{1}$ dapat diterima. Variabel PRCL dinilai menggunakan indeks dengan nilai 1 hingga 7, yakni semakin baik hak berpolitik dan kebebasan pribadi pada suatu negara maka semakin kecil nilai indeks pada variabel ini. Oleh karena itu, nilai koefisien ini menunjukkan bahwa semakin baik hak berpolitik dan kebebasan pribadi di suatu negara, tingkat pengungkapan sosialbank syariah di negara tersebut juga meningkat.

Variabel MUSPOP secara statistik signifikan pada significance-level sepuluh persen, dengan nilai koefisien 0,138590. Nilai ini menunjukkan bahwa proporsi penduduk muslim pada suatu negara secara signifikan berpengaruh positif pada tingkat pengungkapan sosial bank syariah, sehingga $\mathrm{H}_{2}$ dapat diterima Akan tetapi, nilai probabilitas yang cukup besar mengindikasikan bahwa hubungan positif antara MUSPOP dan EII ini tidak sebesar yang diprediksi.Hubungan yang tidak sekuat prediksi berdasar penelitian sebelumnya ini mungkin dapat terjadi karena saat ini perbankan syariah telah menyebar ke banyak negara, bahkan negara minoritas muslim. Negaranegara ini umumnya menjalankan perbankan syariah dengan standar yang hampir sama dengan negara mayoritas muslim yang mereka jadikan acuan. Oleh karena itu, pengungkapan sosial yang dilakukan perbankan syariah di negara tersebut cukup baik walaupun tidak ada tuntutan kuat dari publik relevan.

${ }^{3}$ Pemilihan model ini dilakukan menggunakanHaussman test. Chow test tidak dilakukan karena Chow test tidakrelevan. Regresi tidak dapat diestimasi menggunakan FEM karena adanya variabel yang nilainya tidak berubah antarperiode, yakni MUSPOP. Sehingga kesimpulan model yang digunakan dapat langsung diambil hanya dengan haussman test. 
Variabel IGSCORE memiliki nilai probabilitas paling rendah dan membuktikan bahwakualitas Islamic Governance berpengaruh positif pada tingkat pengungkapan sosial bank syariah. Informasi ini menunjukkan bahwa $\mathrm{H}_{3}$ dapat diterima. Nilai ini juga menunjukkan bahwa Sharia Supervisory Board (SSB) memang merupakan elemen yang sangat penting bagi bank syariah terkait dengan inisiatif sosial dan kepatuhan terhadap nilai-nilai Islam.

Proporsi IAH dibandingkan total aset menunjukkan model operasi bank syariah, yakni apakah mereka merupakan bank yang berfokus pada intermediasi dana, jasa murabahah, investasi, atau kegiatan lain. Variabel IAH ternyata secara statistik tidak signifikan mempengaruhi tingkat pengungkapan sosial, sehingga $\mathrm{H}_{4}$ tidak terbukti. Informasi ini menunjukkan bahwa model operasi bank syariah, apakah mereka berfokus pada intermediasi dana atau kegiatan lain, tidak signifikan mempengaruhi pengungkapan sosial bank tersebut. Ketika sebuah bank sudah menyatakan diri sebagai bank syariah, ekspektasi masyarakat tidak dipengaruhi oleh model operasi bank tersebut. Masyarakat akan mengharapkan bank tersebut beroperasi dan menyampaikan informasi sesuai harapan mereka tentang bank syariah. Oleh karena itu, variabel IAH ini tidak statistik signifikan mempengaruhi pengungkapan sosial.Variabel GDP adalah satu-satunya variabel yang walaupun secara statistik signifikan mempengaruhi tingkat pengungkapan sosial, hubungan ini tidak sesuai dengan prediksi. Koefisien variabel ini menunjukkan pengaruh negatif antara GDP per kapita sebuah negara dengan tingkat pengungkapan sosial bank syariah, sehingga $\mathrm{H}_{5}$ tidak terbukti. Hasil ini menunjukkan bahwa hubungan antara kondisi ekonomi negara dengan pengungkapan perusahaan memang sulit untuk diprediksi karena adanya beberapa penelitian yang mengemukakan hasil yang berbeda-beda. Kesulitan ini sebagian disebabkan karena kondisi perekonomian negara akan memberikan pengaruh berbeda-beda terhadap jenis industri yang berbeda (Williams 1999; Xiao et al. 2005). Dalam konteks perbankan syariah, naik-turunnya kondisi ekonomi negara tidak memberikan dampak kepada operasional bank syariah sebesar sektor lain. Kondisi ini disebabkan karena bank syariah, terutama yang berfokus pembiayaan, memang lebih tahan terhadap gejolak kondisi ekonomi sehingga elastisitas mereka terhadap perubahan kondisi ekonomi tidak terlalu besar.

Variabel ASET pada penelitian ini ternyata signifikan pada significance-leve/ lima persen. Hasil ini berbeda dengan penelitian Farook, Hassan, dan Lanis (2011). Perbedaan ini kemungkinan besar terjadi karena penelitian ini memasukkan variabel baru, yakni variabel GDP sebagai ukuran kondisi ekonomis suatu negara.Variabel GDP bisa jadi telah menangkap sebagian pengaruh variabel ASET kepada EII, sehingga pengaruh variabel ASET sendiri kepada EII tidak signifikan.Kondisi ini dibuktikan oleh nilai korelasi variabel GDP dan ASET yang signifikan. Nilai adjusted $R$-square pada Regresi 1 ini sebesar 0,217615. Nilai ini menunjukkan bahwa model ini dapat menjelaskan sekitar 22 persen dari nilai EII. Nilai adjusted $R$-square pada penelitian ini memang lebih rendah daripada nilai pada penelitian Farook, Hassan, dan Lanis (2011) sebesar 0,4771, tetapi nilai ini sudah cukup baik untuk menilai tingkat signifikansi tiap variabel independen. Selain itu, probabilitas F-statistic di bawah $1 \%$ menunjukkan bahwa model ini memiliki goodness of fit yang tinggi.

Hubungan antara hak berpolitik dan kebebasan pribadi, populasi muslim, kualitas Islamic Governance, proporsi IAH, dan kondisi ekonomi negara terhadap kinerja keuangan dengan pengungkapan sosial sebagai variabel pemediasi. Hasil estimasi regresi kedua dan ketiga untuk pengujian $\mathrm{H}_{6}$ hingga $\mathrm{H}_{7}$ menunjukkan hasil sebagai berikut.

Tabel 4. Hasil Regresi 2 untuk Hubungan antara Variabel Pemediasi (EII) dan Variabel Dependen (ROA)

\begin{tabular}{|c|c|c|c|}
\hline Variabel & Prediksi Hubungan & Koefisien & P-Value \\
\hline Konstan & & 0.007254 & 0.5311 \\
\hline EII & + & 0.004591 & 0.8656 \\
\hline \multicolumn{2}{|c|}{$\begin{array}{c}\text { Adjusted R-Squared } \\
\text { Prob (F-statistic) }\end{array}$} & \multicolumn{2}{|c|}{$\begin{array}{l}-0.009709 \\
0.865553\end{array}$} \\
\hline
\end{tabular}

Regresi 2 ini bertujuan untuk mengetahui apakah variabel pemediasi (EII) mempengaruhi variabel dependen (ROA). Tabel 4 menunjukkan bahwa variabel pemediasi tidak mempengaruhi variabel dependen. Hal ini mengindikasikan bahwa EII tidak memediasi hubungan antara variabel independen (variabel kontekstual) dengan variabel dependen (ROA).

Bank syariah di Indonesia merupakan contoh bagus tentang bagaimana pengungkapan sosial ternyata tidak signifikan mempengaruhi kinerja keuangan. Bank syariah di Indonesia memiliki tingkat pengungkapan sosial yang cukup tinggi dibandingkan negara lain. Akan tetapi, bank syariah di Indonesia memiliki nilai ROA yang tidak jauh berbeda dengan bank di negara lain yang memiliki tingkat pengungkapan sosial lebih rendah. Kondisi ini dapat terjadi karena industri bank syariah di Indonesia belum cukup mapan. Perbankan syariah belum mencapai target 5 persen dari total aset perbankan nasional. Pola pikir sebagian besar masyarakat Indonesia belum mempertimbangkan bank syariah sebagai sebuah 'lembaga bisnis'. Sehingga, ketika bank syariah mampu menunjukkan identitas mereka sebagai sebuah bank syariah, hal tersebut tidak banyak mempengaruhi pelanggan 
baru untuk menggunakan jasa bank syariah. Informasi tersebut baru sekedar mempertahankan pelanggan yang telah dimiliki bank syariah tersebut.

Analisis selanjutnya adalah menggunakan Regresi 3 dengan memasukkan baik variabel independen maupun variabel pemediasi yang hasilnya ditampilkan pada Tabel 5. Tabel 5 menunjukkan bahwa variabel EII tidak signifikan mempengaruhi ROA karena memiliki nilai p-value diatas 5\% (0,5938). Kesimpulan yang dapat diambil adalah pengungkapan sosial tidak memediasi hubungan antara variabel independen dengan variabel dependen. Hasil analisis Regresi 2 dan Regresi 3 menunjukkan bahwa $\mathrm{H}_{6}$ dan $\mathrm{H}_{7}$ tidak dapat didukung data.

Tabel 5. Hasil Regresi 3 untuk Hubungan antara Variabel Independen dan Variabel Pemediasi terhadap Variabel Dependen (ROA)

\begin{tabular}{lccc}
\hline \multicolumn{1}{c}{ Variabel } & Prediksi Hubungan & Koefisien & Prob-value \\
\hline Konstan & & $-0,134999$ & 0,0592 \\
EII & $+/-$ & $-0,018984$ & 0,5938 \\
PRCL & $+/-$ & 0,001801 & 0,6717 \\
MUSPOP & $+/-$ & 0,012272 & 0,6712 \\
IGSCORE & $+/-$ & $-0,001451$ & 0,7292 \\
IAH & $+/-$ & 0,039445 & 0,0400 \\
GDP & $+/-$ & $-7,35 \mathrm{E}-08$ & 0,7188 \\
ASET & $+/-$ & 0,005499 & 0,1152 \\
\multicolumn{2}{c}{0,047654} \\
\multicolumn{2}{c}{0,099483} \\
\hline
\end{tabular}

\section{Simpulan}

Penelitian ini bertujuan menguji variabel kontekstual apa saja yang mempengaruhi tingkat pengungkapan bank syariah. Setelah itu, penelitian ini juga bertujuan menguji apakah tingkat pengungkapan sosial memediasi hubungan antara faktor kontekstual dengan kinerja keuangan bank syariah. Sampel penelitian ini adalah 34 bank syariah dari berbagai negara selama 2010-2012, sehingga penelitian ini menggunakan model data panel. Penelitian ini menemukan bahwa variabel kontekstual yang signifikan mempengaruhi pengungkapan sosial adalah hak berpolitik dan kebebasan pribadi suatu negara, populasi muslim, kualitas Islamic governance, kondisi ekonomi negara, dan ukuran bank syariah. Penelitian ini tidak menemukan hubungan signifikan antara tingkat pengungkapan bank syariah dengan kinerja.Hal ini berarti bahwa pengungkapan sosial tidak memediasi hubungan antara variabel kontekstual dan kinerja keuangan.Dengan demikian, penelitian ini menemukan bahwa tingkat pengungkapan bank syariah tidak memediasi hubungan antara variabel kontekstua dengan kinerja.

Hasil penelitian ini harus dibaca dengan hati-hati karena beberapa keterbatasan yang ada dalam penelitian ini. Keterbatasan pertama adalah jumlah sampel yang masih terbatas. Sebagian besar bank syariah di banyak negara hanya mempublikasikan laporan keuangan tanpa pengungkapan tambahan. Akibatnya, sebagian besar bank tersebut tidak dapat menjadi sampel penelitian. Selain itu, banyak bank syariah yang tidak konsisten dalam mempublikasikan laporan tahunan sehingga tidak dapat menjadi sampel.

Keterbatasan kedua adalah ukuran kinerja keuangan yang hanya menggunakan ukuran akuntansi (ROA) karena keterbatasan informasi dari bank syariah yang menjadi sampel. Akibatnya, sangat mungkin ada perubahan kinerja keuangan yang tidak tertangkap oleh ukuran akuntansi ini.

Berdasar keterbatasan-keterbatasan tersebut, penelitian ini memberikan beberapa saran untuk penelitian berikutnya. Penelitian selanjutnya sebaiknya memperluas populasi menjadi bank syariah di seluruh dunia, sehingga jumlah sampel dapat diperbanyak dengan memasukkan lebih banyak bank syariah dari negara-negara non-GCC. Jumlah observasi juga sebaiknya diperbanyak dengan memasukkan data antar waktu yang lebih panjang daripada jangka waktu tiga tahun yang digunakan dalam penelitian ini. Penelitian selanjutnya juga dapat berusaha memasukkan sampel yang menyediakan informasi nilai pasar bank syariah tersebut. Pengungkapan sosial dapat menciptakan aset tak berwujud seperti perubahan reputasi di mata konsumen maupun perubahan pandangan investor. Perubahan kinerja seperti ini hanya dapat ditangkap oleh ukuran dengan nilai pasar.

\section{Daftar Refrensi}

AAOIFI. 2003. Accounting, Auditing, and Governance Standards for Islamic Financial Institutions. AAOIFI.

Abdullah, D. V., dan K. Chee. 2012. Buku pintar keuangan syariah. Zaman.

Aerts, W., D. Cormier, dan M. Magnan. 2008. Corporate environmental disclosure, financial markets and the media: An international perspective. Ecological Economics 64 (3): 643-659. 
Al-Deehani, T., R. A. A. Karim, dan V. Murinde. 1999. The capital structure of Islamic Banks under the contractual obligation of profit sharing. International Journal of Theoretical and Applied Finance 2 (3): 243-283.

Al-Tuwaijri, S. A., T. E. Christensen, dan K. Hughes. 2004. The relations among environmental disclosure, environmental performance, and economic performance: A Simultaneous Equations Approach. Accounting, Organizations and Society 9 (5-6): 447-471.

Archer, S., R. A. A. Karim, dan T. Al-Deehani. 1998. Financial contracting, governance structures and the accounting regulation of Islamic banks: An analysis in terms of agency theory and transaction cost economics. Journal of Management and Governance 2 (2): 149-170.

Balmer, J. M.T., dan E. R. Gray. 2000. Corporate identity and corporate communications: creating a competitive advantage. Industrial and Commercial Training 32 (7): 256-262.

Berrone, P., J. Surroca, dan J. A. Tribó. 2007. Corporate ethical identity as a determinant of firm performance: A Test of the mediating role of stakeholder satisfaction. Journal of Business Ethics 76 (1): 35-53.

CIA. 2013. The world factbook. Diakses 20 Maret 2014, dari https://www.cia.gov/library/publications/the-worldfactbook/.

Deegan, C., M. Rankin, dan J. Tobin. 2002. An examination of the corporate social and environmental disclosures of BHP from 1983-1997: A test of legitimacy theory. Accounting, Auditing \& Accountability Journal 15 (3): 312-343.

Doupnik, T. S., dan S. B. Salter. 1995. External environment and accounting aractice: A preliminary test of a general model of International accounting development. The International Journal of Accounting, Education and Research 30 (2): 189-207.

El-Hawary, D., W. Grais, dan Z. Iqbal. 2004. Regulating Islamic financial institutions: The nature of the regulated. WPS 3227. Policy, Research Working Paper. Washington, DC. Diakses dari http://documents.worldbank.org/curated/en/918931468761945251/Regulating-islamic-financialinstitutions-The-nature-of-the-regulated .

Farook, S. 2008. Social responsibility for Islamic Financial institutions: Laying down a framework. Journal of Islamic Economics, Banking and Finance 4 (1): 61-82.

Farook, S, M K. Hassan, dan R. Lanis. 2011. Determinants of corporate social responsibility disclosure: The case of Islamic banks. Journal of Islamic Accounting and Business Research 2 (2): 114-141.

Freedom in the World. 2011. The authoritarian challenge to democracy. Diakses 11 Maret 2014, dari: https://freedomhouse.org/report/freedom-world/freedom-world-2011\#.U319GoF_tsI.

2012. The Arab uprisings and their global repercussions. Diakses 11 Maret 2014, dari : https://freedomhouse.org/report/freedom-world/freedom-world-2012.

—. 2013. Democratic breakthroughs in the balance. Diakses 11 Maret 2014, dari: https://freedomhouse.org/report/freedom-world/freedom-world-2013\#.U3I9SoF_tsI.

Gambling, T.E., dan R.A.A. Karim. 1986. Islam and 'social accounting.' Journal of Business Finance \& Accounting 13 (1): 39-50.

Global Capital. 2013. The world best Islamic banks. Diakses 10 Maret 2014, dari Global Capital, April. http://www.globalcapital.com/article/k3360fz3qvh4/the-worlds-best-islamic-banks.

Global Finance. 2011. Islamic bank awards 2011: overall awards. Diakses 12 Maret 2014, dari Global Finance. http://www.gfmag.com/magazine/june-2011/islamic-bank-awards-2011-overall-awards-.

2012. World's best Islamic financial institutions 2012. Diakses 12 Maret 2014, dari Global Finance, April. $\quad$ www.gfmag.com/archives/139/11274-islami-bank-awards-2011-overallawards.htmlwww.gfmag.com/awards-rankings/best-banks-and-financial-rankings/worlds-best-islamicfinancial-institutions-2012.

2013. Awards: best Islamic banks 2013. Diakses 12 Maret 2014, dari Global Finance, June. http://www.gfmag.com/magazine/june-2013/awards-best-islamic-banks-2013.

Gujarati, D N., dan D. C. Porter. 2009. Basic econometrics. 5thed. New York: McGraw-Hill Irwin. 
Haniffa, R, and M. Hudaib. 2007. Exploring the ethical identity of Islamic banks via communication in annual reports. Journal of Business Ethics 76 (1): 97-116.

Hassan, M. K. 1999. Islamic Banking in theory and practice: The experience of Bangladesh. Managerial Finance 25 (5): 60-113.

Hillman, A. J., dan G. D. Keim. 2001. Shareholder value, stakeholder management, and social issues: What's the bottom line? Strategic Management Journal 22 (2): 125-139.

IMF. 2013. World economic outlook database. Diakses 5 April 2014, dari International Monetary Fund. http://www.imf.org/external/pubs/ft/weo/2013/02/weodata/index.aspx.

Khan, F. 2010. How 'Islamic' is Islamic banking. Journal of Economic Behavior \& Organization 76 (3): $805-820$.

Khir, K., L. Gupta, dan B. Shanmugam. 2008. Islamic banking: a practical perspective. Petaling Jaya, Selangor Darul Ehsan : Pearson Longman.

Maali, B., P. Casson, dan C. Napier. 2006. Social reporting by Islamic banks. Abacus 42 (2): 266-289.

Margolis, J. D., dan J. P. Walsh. 2003. Misery loves companies: Rethinking social nitiatives by business. Administrative Science Quarterly 48 (2): 268-305.

McWilliams, A., dAN D. Siegel. 2000. Corporate social responsibility and financial performance: correlation or misspecification?. Strategic Management Journal 21 (5): 603-609.

Milne, M. J, and R. W Adler. 1999. social and environmental disclosures exploring the reliability of social and environmental disclosures content analysis. Auditing \& Accountability Journal 12 (2): 237-256.

Newson, M., Dan C. Deegan. 2002. Global expectations and their association with corporate social disclosure practices in Australia, Singapore, and South Korea. The International Journal of Accounting 37: 183-213.

Rahman, A. A., dan A. A. Bukair. 2013. The influence of the shariah supervision board on corporate social responsibility disclosure by Islamic banks of gulf co-operation council countries. Asian Journal of Business and Accounting 6 (2): 65-105.

Riahi-Belkaoui, A., and A. Belkaoui. 1985. International accounting: issues and solutions. westport, Connecticut: Quorum Books.

Richardson, A. J., dan M. Welker. 2001. Social disclosure, financial disclosure, and the cost of equity capital. Accounting Organizations and Society 26: 597-616.

Sehrish, S., F. Saleem, M. Yasir, F. Shehzad, dan K. Ahmed. 2012. Financial performance analysis of Islamic banks and Conventional banks in Pakistan: A comparative study. Interdisciplinary Journal of Contemporary Research in Business 4 (5): 186-200.

Sufian, F. 2010. Does foreign presence foster Islamic banks' performance? empirical evidence from Malaysia. Journal of Islamic Accounting and Business Research 1 (2): 128-147.

Sulaiman, M., dan R. Willett. 2003. Using the hofstede-gray framework to argue normatively for an extension of Islamic corporate reports. Malaysian Accounting Review 2 (1): 81-105.

The Asian Banker. 2010. Most of the world's largest Islamic banks are concentrated in only five markets. The Asian Banker. Diakses dari http://www.theasianbanker.com/workspace.html?mod=default\&method=download\&p=xgUgPkACJOGk KwBjdyYP7aK7FwG\%2BHsGOmfQtjrWZHF0W\%2FMpRqXgVFOsItEaCLOxoLFSkBhMoJvS\%2Bd12z8 8Lv6w\%3D\%3D.

Triyuwono, I. 2012. Akuntansi syariah: Perspektif, metodologi, dan teori. Edisi 2. Jakarta: Raja Grafindo Persada.

Williams, S. M. 1999. Voluntary environmental and social accounting disclosure practices in the Asia-Pacific region: An international empirical test of political economy theory. The International Journal of Accounting 34 (2): 209-238.

Xiao, J. Z., S. S. Gao, S. Heravi, dan Y. C. Q Cheung. 2005. The impact of social and economic development on corporate social and environmental disclosure in Hong Kong and the U.K. Advances in International Accounting 18: 219-243. 
Lampiran 1. Daftar Bank Syariah yang Menjadi Sampel Penelitian

\begin{tabular}{|c|c|c|}
\hline No & Nama Bank Syariah & Asal Negara \\
\hline 1 & Al Rajhi Bank & Arab Saudi \\
\hline 2 & Al Baraka Islamic Bank B.S.C. & Bahrain \\
\hline 3 & Bahrain Islamic Bank (BiSB) & Bahrain \\
\hline 4 & Al Salam Bank & Bahrain \\
\hline 5 & Ithmaar Bank & Bahrain \\
\hline 6 & Elaf Bank & Bahrain \\
\hline 7 & Gulf Finance House (GFH) & Bahrain \\
\hline 8 & Islami Bank Bangladesh Limited (IBBL) & Bangladesh \\
\hline 9 & Al Baraka Bank - South Africa & Afrika Selatan \\
\hline 10 & Bank Islam Brunei Darussalam (BIBD) & Brunei Darussalam \\
\hline 11 & Bank Muamalat Indonesia (BMI) & Indonesia \\
\hline 12 & Bank Syariah Mandiri (BSM) & Indonesia \\
\hline 13 & Bank of London and the Middle East (BLME) & Inggris \\
\hline 14 & Jordan Islamic Bank & Yordania \\
\hline 15 & Boubyan Bank & Kuwait \\
\hline 16 & Kuwait Finance House (KFH) & Kuwait \\
\hline 17 & Bank Rakyat & Malaysia \\
\hline 18 & Bank Islam Malaysia & Malaysia \\
\hline 19 & HSBC Amanah Malaysia Berhad & Malaysia \\
\hline 20 & RHB Islamic Bank Berhad & Malaysia \\
\hline 21 & Meezan Bank & Pakistan \\
\hline 22 & Masyraf Al Rayan & Qatar \\
\hline 23 & Qatar Islamic Bank (QIB) & Qatar \\
\hline 24 & Qatar International Islamic Bank (QIIB) & Qatar \\
\hline 25 & Al Baraka Bank - Sudan & Sudan \\
\hline 26 & Al Shamal Islamic Bank & Sudan \\
\hline 27 & Faisal Islamic Bank - Sudan & Sudan \\
\hline 28 & Al Baraka Bank - Tunisia & Tunisia \\
\hline 29 & Bank Asya & Turki \\
\hline 30 & Kuveyt Turk & Turki \\
\hline 31 & Turkiye Finans & Turki \\
\hline 32 & Abu Dhabi Islamic Bank & UAE \\
\hline 33 & Al Hilal Bank & UAE \\
\hline 34 & Emirates Islamic Bank & UAE \\
\hline
\end{tabular}

